\title{
An Analysis on Occupational upward Mobility of Directional Migration Workers in "Henan Exhibition Village" of Beijing
}

\author{
Tingting Li \\ Beijing North China Electric Power University, No. 2 , Bei Nong Road, Changping District, Beijing, \\ China \\ 18810786820@163.com
} Keywords: Migrant workers; Directed migration; The occupational upward mobility; Migrant
workers occupational school

\begin{abstract}
Influenced by geopolitical and kinship relationships, the flow of migrant workers become agglomerate and directional and forms "Henan Village", "Zhejiang Village", "Henan exhibition village" of migrant workers gathering area in Beijing. This paper investigates the distribution of occupational directed migration of migration workers in "Henan exhibition village" and analyses the possibilities of directional migration workers' occupational upward mobility. The result shows that the directed migration of migrant workers, without the help of government and outside, migrant workers have extremely small chances of upward occupational mobility. The major limiting factor in upward occupational mobility of migrant workers is the lack of the human capital of farmer-workers. Finally, the article points out that our country should provide professional skills training and management skills for migrant workers to help migrant workers increasing occupational upward mobility.
\end{abstract}

\section{Introduction}

The large-scale population migration has been going on for years. A large scale of population moves from underdeveloped regions to developed area and they are working and living in economically developed areas throughout the year [1]. Research shows that migrant workers in geopolitical and kinship-based social network play an important role in the job rationing among urban labor markets or employment model [2]. Effected by this social network, a new phenomenon that migrant workers from the same native place doing the same jobs in the same areas, which is directed migration. For example: in the 1990s, numerous marginal groups had formed in suburban areas of Beijing. These groups have a typical feature that the major members in the same group come from the same native place. Therefore, according to the geographical origin province of the members, the place where they lived was called "X Village"( $\mathrm{X}$ refers to the name of their origin province). At that time, "Zhejiang Village" in peripheral areas of Beijing's third ring road, "Xinjiang Village" in Ganjiakou subdistrict, and "Henan Village" in Erlizhuang area and many other villiages had formed in Beijing [3]. In recent years, people from Henan Province who live in "Henan Exhibition Village" in Magezhuang Village work in exhibition service industry.

The "Henan Exhibition village" began to develop in the late 1990s. A significant reason of the formation of "X Village" is population migration which has been existed in China for years. As long as China still has population migration, "X Village" will appear in different forms in different places. So in the context of the process of urbanization promoting, how to develop the "X Village" in the future? Under the background of industrial structure upgradation, researches about the employment development of migrant workers who live in "X Village" will have great significance. This article takes "Henan Exhibition village" as an example to analyze occupational upward mobility of directional migration workers.

\section{Literature Review}

During the transition from traditional rural society into modern urban society, migrant workers will definitely go through the process of occupational upward mobility. Domestic scholars have 
relatively similar conclusions about the factors which influence migrant workers occupational upward mobility. In recent years, by using of empirical analysis methods scholars have found that the human capital has a decisive role in migrant workers occupational upward mobility. In 2015, Ji Shao and Zhu Zhisheng through empirical analysis conclude that the flow experience and occupation development characteristics of migrant workers show an inverted "U" shaped distribution, adverse selection and downward flow phenomena also exist.

The occupation training is an important factor in their high-end access, while social capital only contributes to the low-end occupation other than the high-end occupation[4]. Tan Yinqing, Wang Zhao, Chen Yifang through logistic regression reached a conclusion that human capital and social capital are important factors in promoting occupational stratification and upward mobility of migrant workers. Due to the economic system reform has weaken the strong relationship between farmers, modernization has erosion original capital of farmers and homogeneity constraints of farmers' social capital itself, human capital has a greater impact on migrant workers' occupational stratification and upward mobility[5].

Most scholars put forward that through vocational training to improve the level of human resources of farmer workers, thereby promoting upward occupational mobility of migrant workers. If migrant workers have a better career development, income growth in their career life will be greater; if the elite of the migrant workforce have a better career development, their occupational income will be increased significantly; migrant workers career development requires vocational skills training and post-secondary education knowledge structure, it is necessary to found Chinese farmers Engineering Vocational University (Zhou Huaming, Zeng Fushengs, 2011) [6]. In 2011, Guo Shuzhen studied whether the new generation of migrant workers willing to stay in the city and explore their career path by using a hierarchical classification technique, finally she put forward a variety of career paths selections such as dual type, screw type, jumping type, etc. [7]. Willingness of migrant workers should be based on the training of migrant workers. Meanwhile, we should build modern national vocational education and training services system which focusing on the convergence of input and output areas, establish a vocational education and training system which dominant by government, school - enterprise as the main body, supplied by non-governmental organizations. Compensation vocational education training consisted mainly by the new generation of migrant workers should be strengthen（Ma Jianfu, 2014）[8].

\section{The Formation and Occupational Distribution of "Henan Exhibition Village"}

Residents in Beijing "Henan Exhibition Village" refers to migrant workers from Henan engage in the exhibition industry in Beijing. "Henan Exhibition Village" is located in Jinzhan village of Chaoyang District. Residents of "Henan Exhibition Village" gathering in Magezhuang village mostly come from Qingfeng county Nanle county of Henan Province. A majority of these workers are male, aging between about 15-60 years old, whose educational levels is junior high school. Besides, most of them have carpentry. After development for over ten years, "Henan exhibition village" has internal stratification, some of them become private entrepreneurs, and others become ordinary workers. At the same time, "Henan Exhibition Village" reflects a collection of different geographical origin affiliate. A private entrepreneur who comes from Qingfeng county Macunxiang villiage of Henan Province, then the vast majority workers of his factory also come from Qingfeng county and Nanle county of Henan Province. By analyzing agglomeration characteristics of residents in "Henan Exhibition village", it is found that villagers base on geographical and kinship of Henan province and take the factory as the basic unit to engaging in in the exhibition services industry on the suburb areas of Beijing. "Henan Exhibition Village" has the same plant operating mode that migrant workers imitate those forerunner whom have been succeeded. Migrant workers can expand "village" which based on factory as a unit gradually. When "Henan Exhibition Village" expand to a certain extent, the village will attract other migrant workers come from the same region to working in other industries. Accordingly, villagers of "Henan Exhibition village" have more types of occupations to engage and the structure has improved steadily. 
Initially, Henan people who were working in the decoration move to exhibition services industry gradually and they involved in involving various positions of exhibition services. Furthermore, they relied on the exhibition industry to develop its own service industry which continuing attract more Henan people directed migrating to Magezhuang village. The first batch of migrant workers came to Magezhuang village was only engaged in the production and build of booth. Then, there were more and more workers gradually engaged in related artwork and booth design work related to exhibition. With the accumulation of wealth and experience, some people become private entrepreneurs who set up factories to product booth, build facility and art plant. They provide more jobs for more Henan people in Beijing. In recent years, the exhibition industry enjoys a rapid development in Guangzhou, Shanghai and Wuhan. Some private entrepreneurs are copying this model to open branches in Shanghai. According to the survey, there are some private entrepreneurs have begun to develop into upstream of exhibition industry and involve in exhibition design in order to improve the company's business structure. The increase of directed migration personnel has prompting them to develop their own services industry. In recent years, some villagers from Qingfeng County and Nanle County of Henan Province have been started restaurant industry and their own bus transportation.

The Limitations of upward occupational mobility of migrant workers in "Henan Exhibition Village". After ten years of development, migrant workers in "Henan Exhibition Village" have been start occupational stratification, migrant workers can be divided into primary migrant workers, technical workers, senior technical migrant workers and entrepreneurs of migrant workers. The entrepreneurs of migrant workers engaged in booth production and construction have achieved "de-physical", the entrepreneurs specialized in exhibition design has realized "de-migrant workers". The process of migrant workers gradually realize the "non-manual" and "de-migrant workers" is called occupational upward mobility.

In accordance with the survey, it is known that vast majority of migrant workers in "Henan Exhibition Village" is the exhibition industry workers, a small part of elite migrant workers become entrepreneurs, and very small part of the entrepreneurs open the exhibition design company. By analyzing the current status of migrant workers' employment of "Henan Exhibition Village", it is found that in the process of upward occupational mobility of migrant workers, there are some barriers in the flow between classes, thus the development of the private company is limited due to the lack of human capital. Primary migrant workers can only be move upward to the advanced technology of migrant workers, while most private entrepreneurs only develop in the downstream of exhibition services. Although the "physical" migrant workers have a strong willingness to upward mobility, but capital and human capital constraint the upward development of migrant workers. The lack of the entire group of middle managers, restrictions on private entrepreneurs' management ability hindered the expansion of business scale and the process of business model replication.

\section{Conclusions and Suggestions}

Through the above analysis, as a marginal social group in Beijing, "Henan Exhibition Village" can hardly gain further development without injection of outside capital or human resources. It's tough for migrant workers having no professional technique or management skills to get occupational upward mobility. In the context of the accelerating process of urbanization, it's rather vital to solve the problems in occupational upward mobility of migrant workers. In this paper several suggestions will be offered for occupational upward mobility of migrant workers in "Henan Exhibition Village".

Labor Output Location: Government of Henan Province. The Henan government can offer trainings for migrant workers on professional techniques, management skills and enterprise administrative management skills, via establishing new types of migrant worker vocational school. As for the model of school, we can learn from APPOLO model of US, the market of school targets at low-end higher education, and the purpose is to improve occupational upward mobility of migrant workers [9]. Besides, referring to MES(Modules of Employable Skill) developed by International Labor Organization, online modularized curriculum can be provided. Migrant workers 
can get access to online courses and study professional techniques and management skills by themselves in their spare time, which are demanded for their occupational upward mobility. Government of Henan province and private entrepreneurs can cooperate on orientation training and orientation labor output for migrant workers who accomplished the training. This measure would achieve an all-win situation. In addition to provide skill training, government should offer petty loan for startups, help private entrepreneurs expanding the business scale to develop aiming at upstream of the exhibition business, and use the business pattern as reference for other cities where exhibition business is well developed, in order to solve the problems of migrant workers outgoing and occupational upward mobility.

Migrant Workers of "Henan Exhibition Village". Migrant workers should have clear plans for their own further career, then attend training courses, continue learning and acquire professional skills required by occupational upward mobility. The new generation of migrant workers can take consideration of learning exhibition designing to achieve migrant migrants' occupation "de-physical". Workers with advanced techniques can teach acknowledge of management themselves and shift to startups or exhibition business managers. Private entrepreneurs shall study operation management to improve the fund application ability and enlarge the scale of enterprises, which could provide more jobs.

As a marginal social group, the migrant workers of "Henan Exhibition Village" can establish labor union organization for a better protect for their own rights and interests. Labor union is able to coordinate the relation between migrant workers, output location city and government, set common business standard and promote the Henan exhibition brand [10]. Labor union organizes and manages the skill training, increases the number of middle management, improves entrepreneurs' operation management skills, enlarge the enterprise scale of Henan Exhibition Village, and use the business pattern as reference for other cities to gain more profits.

The Government of Beijing. As a destination of migrant workers, Beijing has structural imbalances in the employment of migrant workers. Skilled migrant workers with management skills are badly demanded in the human resource market, this situation contradicts the lack of current human capital. Beijing is a highly-developed city with good conditions of vocational education. The government of Beijing should engage with the training from the Government of Henan province, Henan government to provide training before the labor output, and Beijing government should provide continuing education with the power of multiple sources. There are plenty of colleges and universities sources to establish community organizations, and college student volunteers can also offer training and guidance for the career planning of migrant workers' occupational upward mobility.

The directional migration group like "Henan Exhibition Village" is a widespread phenomenon all around China. Joint effort is required from origin areas, migrant workers themselves and destination areas to improve these migrant workers' occupational upward mobility. In the process of migrant workers' occupational upward mobility, skill training and continuing education play decisive roles. Without involve of government and external factors, migrant workers under directional migration cluster employment have to face the bottlenecks in development due to the limitation of human capital. The occupational upward mobility of migrant workers is in urgent need of guidance, relating training and financial support for startups from government.

\section{References}

[1] X.C. Qiao and Y.H. Huang: Population and Development, Vol. 19 (2013) No.3, p.13

[2] X.Q. Huang, C.H. Miao and K.W. Lu: Areal Research and Development, Vol. 33 (2014) No.4, p.142

[3] Y.C. Meng and G.Z. Cao: Human Geography, Vol. 12 (1997) No.4, p.5

[4] S. Ji and Z.S. Zhu: Social Sciences of Beijing, （2015） No.1, p.4

[5] Y.Q. Tan, Z. Wang and Y.F. Chen: The World of Survey and Research, (2015) No.9, p.57 
[6] H.M. Zhou and F.S. Zeng: Social Sciences in Hunan, (2011) No.6, p.111

[7] S.Z. Guo: Journal of Shaanxi University of Technology (Social Sciences), Vol. 29 (2011) No.2, p: 22

[8] J.F. Ma: Research in Educational Development, (2014) No.9, p.7

[9] H.M. Zhou: Studies on the Career Developing Issue in China Peasant-worker (Ph. D, Hunan Agricultural University, China 2012), p.40

[10]H.Y. Li: Studies on Migrant Workers in Construction (Ph. D, Dongbei University of Finance \& Economics, China 2007), p.192 